\title{
Pijnloze zwelling bleek een centrale reuscellaesie
}

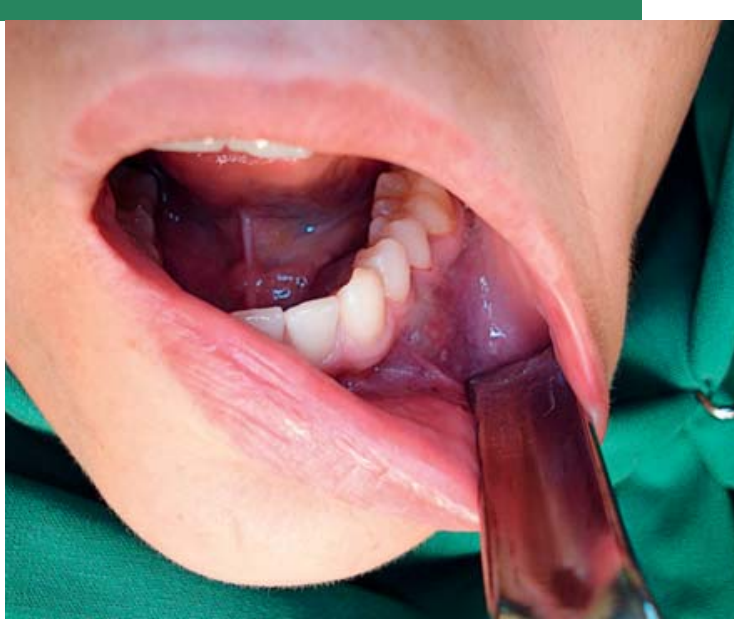

Afb. 1. Zowel linguaal als buccaal van gebitselementen 34 en 35 is een blauw-doorschemerende zwelling zichtbaar.

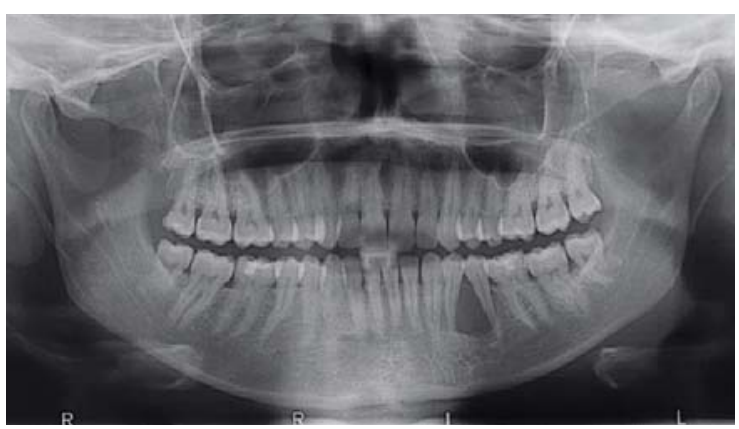

Afb. 2. Op de panoramische röntgenopname is tussen gebitselementen 34 en 35 een goed begrensde radiolucente afwijking zichtbaar met divergentie van de radices van de betrokken gebitselementen.

\section{Anamnese}

De patiënt had een blanco voorgeschiedenis. Bij intraoraal onderzoek werd een goed onderhouden dentitie gezien. Zowel linguaal als buccaal ter plaatse van gebitselementen 34 en 35 bevond zich een pijnloze, vast-elastisch aanvoelende, bolronde, blauw-doorschemerende afwijking (afb. 1). Er was geen sprake van verhoogde mobiliteit van de desbetreffende gebitselementen, percussiepijn of pockets en beide gebitselementen reageerden positief op de sensibiliteitstest. De sensibiliteit in het verzorgingsgebied van de nervus alveolaris inferior aan de linkerzijde was ongestoord.

Op een vervaardigde panoramische röntgenopname werd tussen de wortels van beide premolaren een circumscripte radiolucentie gezien die reikte tot het foramen mentale. De radices divergeerden als gevolg van het aanwezige proces. Wortelresorptie was op de röntgenopname niet zichtbaar (afb. 2).

Om de mogelijke relatie van de afwijking met het foramen mentale en de canalis mandibulae als ook de uitbreiding in

anterieure en posterieure richting te kunnen beoordelen, werd een cone beam-computertomogram (cone beam-CT) vervaardigd. De verkregen data werden afgebeeld in dwarsdoorsneden en in een driedimensionale weergave ( $\mathrm{afb} .3$ ). Daarop was duidelijk te zien dat het foramen mentale aan de afwijking grensde, maar er geen onderdeel vanuit maakte. Het dak van de canalis mandibulae, iets meer posterieur gelegen, liet op de dwarsdoorsneden daarentegen wel een relatie met de afwijking zien. Er was uitgebreid parodontaal aanhechtingsverlies rondom gebitselementen 34 en 35, waardoor de prognose van deze gebitselementen ongunstig was.

Differentieel diagnostisch werd - gezien het beeld en de lokalisatie van de afwijking - gedacht aan een keratocyste, een centrale reuscellaesie of een odontogene tumor. Een excisie van de afwijking zou uitsluitsel moeten geven over de aard van de afwijking.

\section{Diagnostiek en behandeling}

Onder lokale anesthesie werd via een marginale gingiva- 


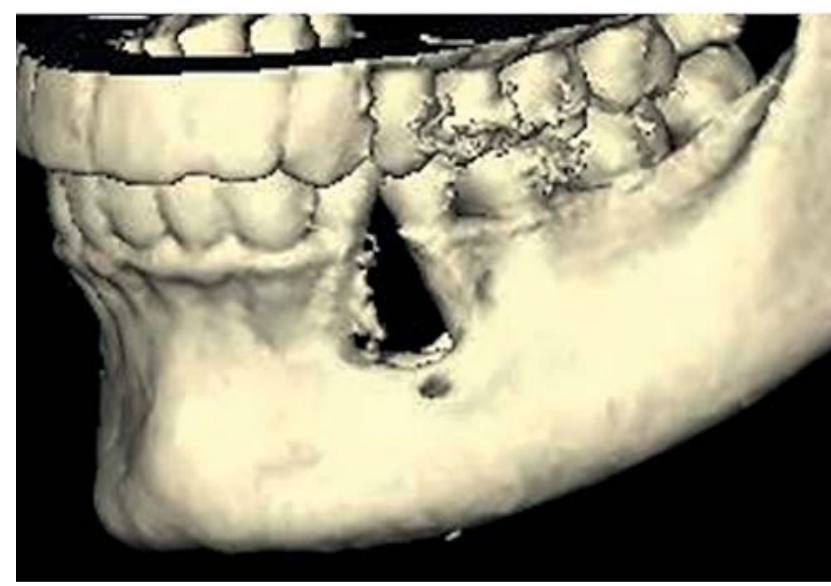

Afb. 3. Driedimensionale reconstructie van de cone beam-CT-data. Het foramen mentale is net caudaal van de afwijking gelegen.

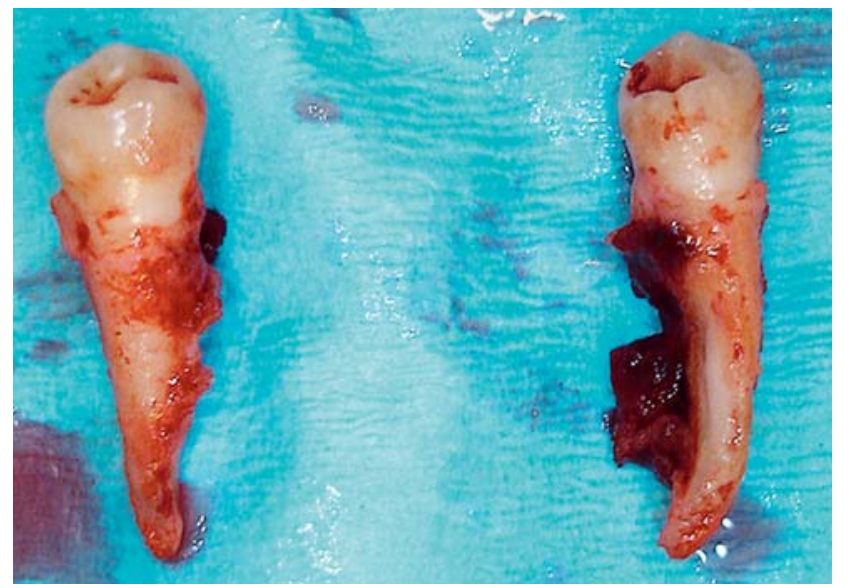

Afb. 4. Resorptie van de gebitselementen zichtbaar over de gehele lengte van de radices.

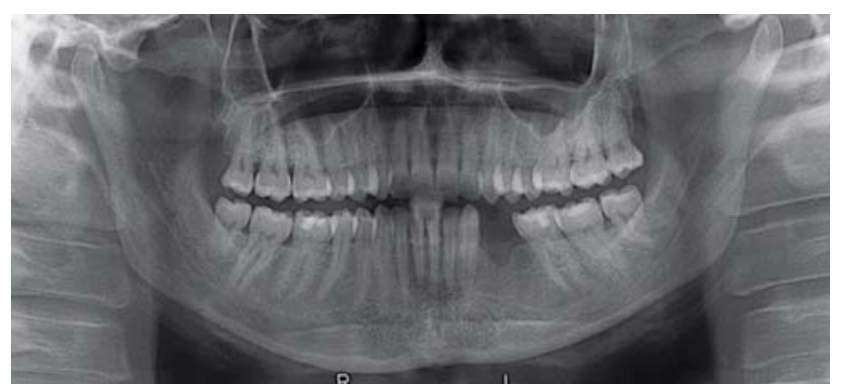

Afb. 5. Panoramische röntgenopname 1 jaar na de behandeling.

incisie een trapeziumvormige buccale mucoperiostlap geprepareerd. Deze liet zich gemakkelijk scheiden van de onderliggende blauwe solide tumor tussen en rond de radices van gebitselementen 34 en 35 . Na verwijdering van de gebitselementen 34 en 35 kon de afwijking geheel worden verwijderd. De wond werd primair gesloten. Wortelresorptie, hoewel röntgenologisch niet zichtbaar, bleek na extractie van gebitselementen 34 en 35 toch aanwezig te zijn (afb. 4). Het histopathologisch onderzoek liet een beeld zien passend bij een centrale reuscellaesie.

Ongeveer 1 jaar na de behandeling had zich klinisch en röntgenologisch geen recidief voorgedaan (afb. 5). Samen met een tandarts-prothetist werd daarom gezocht naar een geschikte methode voor dentale rehabilitatie. De patiënt zag af van uitgebreide rehabilitatie door middel van botaugmentatie en het aanbrengen van implantaten. Daarom werd verwacht dat de keuze zou vallen op een adhesiefbrug ter vervanging van de verwijderde gebitselementen.

\section{Beschouwing}

De centrale reuscellaesie is een niet vaak voorkomende benigne tumor. In het verleden werd deze afwijking aangeduid als centraal reuscelgranuloom of ook wel als centraal reuscellengranuloom (Subramanyam, 2010). De incidentie van voorkomen in de kaak wordt geschat op 0,00011\% (De Lange et al, 2004). De afwijking komt het vaakst voor in de mandibula (Barnes et al, 2005; De Lange et al, 2007). Meestal betreft het dan de premolaar- of molaarregio (De Lange en Van den Akker, 2005; Kruse-Lösler et al, 2006). Hoewel de afwijking op elke leeftijd kan voorkomen, wordt deze vaker bij jonge vrouwen onder de 30 jaar gezien (De Lange en Van den Akker, 2005; Kruse-Lösler et al, 2006).

Het klinisch aspect betreft meestal een niet pijnlijke, blauw-doorschemerende zwelling. De vitaliteit van de naastliggende gebitselementen is intact en vaak is er, ondanks uitgebreide botreductie, geen of weinig mobiliteit van de buurelementen. Tekenen van agressieve groei zoals pijn, paresthesie van de nervus alveolaris inferior of wortelresorptie worden minder vaak waargenomen (De Lange en Van den Akker, 2005).

Het histologische beeld kan niet zonder meer worden onderscheiden van dat van een skeletafwijking ten gevolge van hyperparathyreoïdie: de zogeheten Brown tumor. Het is dan ook belangrijk gericht te vragen naar klachten die hierbij kunnen passen zoals vermoeidheid, misselijkheid en buikpijn, depressiviteit, hypertensie, obstipatie, dorst, vaak en veel plassen en niersteenkolieken, waarbij moet worden opgemerkt dat deze klachten pas ontstaan bij een ernstige vorm van hyperparathyreoïdie. Alleen bij aanwezigheid van meerdere van deze symptomen of in het geval van recidieven is biochemisch onderzoek naar de aanwezigheid van hyperparathyreoïdie aangewezen. Ook kan de afwijking histologisch niet worden onderscheiden van de botafwijking zoals die voorkomt bij cherubisme (De Lange en Van den Akker, 2005). Het onderscheid wordt dan gemaakt op basis van bilateraal voorkomende afwijkingen op röntgenopnamen en de karakteristieke faciale kenmerken zoals het vollemaansgezicht ten gevolge van toename in grootte van de mandibula en soms ook van de maxilla.

Met röntgendiagnostiek kan men een inschatting maken over de uitgebreidheid van de afwijking en de relatie met belangrijke anatomische structuren. Het voordeel van de cone beam-CT boven het maken van een tweedimensionale röntgenopname is dat de tumor en zijn relatie met de omliggende structuren nauwkeuriger te visualiseren is. Ook makkt een driedimensionale reconstructie het voor een patiënt inzichtelijker en begrijpelijker waarom bijvoorbeeld extracties dienen plaats te vinden.

Een zorgvuldige enucleatie van de gehele tumormassa 
met daarbij verwijdering van de in de tumormassa gelegen gebitselementen leidt meestal tot genezing. Een enkele keer komt een recidief voor. De kans hierop is groter bij afwijkingen die een meer agressief groeikarakter vertonen. Een eenvoudige enucleatie zou in zo'n geval onvoldoende zijn. Additionele behandeling met calcitonine of intralaesionale injecties met corticosteroïden zijn een effectieve behandeling voor agressieve, snel groeiende laesies die niet goed reageren op andere therapieën (De Lange en Van den Akker, 2005).

\begin{abstract}
Leermoment
De centrale reuscellaesie is een weinig voorkomende benigne tumor die zich veelal in de premolaar- en molaarstreek van de mandibula manifesteert als een blauw-doorschemerende, pijnloze zwelling. Patiënten hebben meestal geen klachten. Röntgenonderzoek en een cone beam-CT geven een duidelijk beeld van de omvang van de afwijking. De definitieve diagnose kan alleen histopathologisch worden gesteld. De behandeling bestaat uit een zorgvuldige enucleatie van de gehele tumormassa met daarbij verwijdering van de in de tumormassa gelegen gebitselementen en leidt over het algemeen tot genezing.
\end{abstract}

\section{Literatuur}

* Barnes L, Eveson JW, Reichart P, Sidransky D. World Health Organization classification of tumors: pathology and genetics of head and neck tumors. Lyon: IARC, 2005.

* Kruse-Lösler B, Diallo R, Gaertner C, Mischke KL, Joos U, Kleinheinz J. Central giant cell granuloma of the jaws: a clinical, radiologic, and histopathologic study of 26 cases. Oral Surg Oral Med Oral Pathol Oral Radiol Endod 2006; 101: 346-354.

* Lange J de, Akker HP van den, Klip H. Incidence and disease free survival after surgical therapy of central giant cell granulomas of the jaw in The Netherlands: 1990-1995. Head Neck 2004; 26: 792-795.

* Lange J de, Akker HP van den. Clinical and radiological features of central giant-cell lesions of the jaw. Oral Surg Oral Med Oral Pathol Oral Radiol Endod 2005; 99: 464-470.

* Lange J de, Akker HP van den, Berg H van den. Central giant cell granuloma of the jaw: a review of the literature with emphasis on therapy options. Oral Surg Oral Med Oral Pathol Oral Radiol Endod 2007; 104: 603-615

* Subramanyam RV. Misnomers in oral pathology. Oral Dis 2010; 16 : 740-746.

\section{Summary}

Painless swelling proved to be a central giant cell granuloma A 32-year-old female patient was referred to an oral and maxillofacial surgeon with an asymptomatic swelling in the left mandibular premolar region. After extraction of these premolars and enucleation of the lesion histopathological examination confirmed the presence of a giant cell granuloma. This is a benign lesion and enucleation generally results in a permanent cure and is only recurrent in a few cases. Approximately 1 year after treatment, the patient was still free of recurrence and together with a prosthodontist, the appropriate rehabilitation of the resulting defect will be sought.

\section{Bron}

K. Mizbah, R. Barkhuysen, W.L.J. Weijs, S.J. Bergé, M.A.W. Merkx

Uit de afdeling Mondziekten, Kaak- en Aangezichtschirurgie van het Universitair Medisch Centrum St Radboud in Nijmegen

Datum van acceptatie: 8 september 2010

Adres: R. Barkhuysen, UMC St Radboud, huispost 590, postbus 9101, 6500 HB Nijmegen

r.barkhuysen@mka.umcn.nl 